Forthcoming at Social Currents

DOI: https://doi.org/10.1177/2329496517725333

Andrew L. Whitehead and Christopher P. Scheitle

\title{
We the (Christian) People: Christianity and American Identity from 1996 to 2014
}

Religious identity, and specifically Christian identity, has long been a dominant symbolic boundary marker for inclusion into American society. But how has the salience of this boundary marker changed in recent years and in comparison to other boundary markers? Using multiple waves of the General Social Survey (1996, 2004, and 2014), we investigate temporal variation in the use of religion and other markers in constructing symbolic boundaries around American identity. First, we find that the Christian symbolic boundary both increased from 1996 to 2004 and declined from 2004 to 2014. Second, this pattern was not unique; in addition to the Christian symbolic boundary, Americans used a variety of both civic and ascriptive boundary markers in order to define American identity. However, our analysis also demonstrates that in 2004 the Christian symbolic boundary was significantly linked to national identity in a unique way while the other boundary markers were not. These results suggest that period effects and cultural events can influence the salience of religion in creating national symbolic boundaries. We discuss each of these findings, their relationship to the study of symbolic boundaries and American identity, and their societal implications.

Keywords: Christianity, National Identity, Religion, Symbolic Boundaries, United States 


\section{We the (Christian) People: Christianity and American Identity from 1996-2014}

Religion is one area where Americans routinely distinguish between which groups are included and which groups are not (Edgell et al. 2016; Edgell and Tranby 2010). As Edgell and colleagues $(2006,2016)$ note, religion - as opposed to atheism in their studies - is a vital part of the foundation on which the collective identity of Americans rests serving as a "proxy for moral worth." There are, however, competing cultural and historical narratives regarding whether and how religion should define boundaries of membership in the United States.

On the one hand, there exists a narrative that America's history, culture, and identity are defined by a commitment to religious freedom. The idea of the United States as a safe haven for persecuted religions is engrained in children's elementary school lessons about the Pilgrims and Puritans. As Finke (1990:609) argues, "The new boundaries [established by the US] supported a religious market where competition was not only ensured, it was encouraged." This "pluralist nationalist" narrative essentially neutralizes religion's role in defining the line between "us" and "them." It coincides with the values of the "optimistic pluralists" who are generally unwilling to draw symbolic boundaries based on religion (Edgell and Tranby 2010). Within the context of this narrative, an individual should not need to be Christian to be "truly American" and one's sense of national identity should not be defined by a desire to exclude non-Christians.

On the other hand, one can point to a narrative that America's history, culture, and identity are inherently grounded in the Christian faith. Although this narrative became more broadly Christian as religious diversity increased in the $19^{\text {th }}$ and $20^{\text {th }}$ centuries (Fea 2011; Green 2015; Kruse 2015), it consistently refers to the idea that Christianity is essential to the existence of the United States. Those utilizing this narrative largely believe the survival of American culture depends on society's ability to preserve these shared values and history (Edgell and 
Tranby 2010). Within the context of this narrative, being "truly American" means being Christian and basic to that national identity is the exclusion of non-Christians.

Using three waves from a nationally representative data source, we investigate the nexus of these two narratives by examining the intersections of national identity, Christianity, and the drawing of symbolic boundaries around American identity from the mid-1990s until 2014. Prior work on American identity tends to focus on the different types of boundaries Americans place on what it means to be a "true American" (e.g., Schildkraut 2014; Theiss-Morse 2009). This analysis provides a necessary extension of this literature to examine temporal variation in the use of symbolic boundaries, especially religious boundaries, in the United States. We find that in each different decade Americans utilized religion to varying degrees. We also demonstrate that Americans were apt to use a host of characteristics - not just religion - when designating the symbolic boundaries that surround a true American identity. Finally, we establish that while Americans do not privilege religion in the construction of American identity, religion can at times be significantly linked to identification with or feeling close to the United States. Historical events and cultural changes can serve to increase or decrease the salience of religion in forming national symbolic boundaries. These findings and the consequences of them for both civic life in the United States as well as future research on symbolic boundaries and national identity are discussed.

\section{Christianity, National Identity, and Boundaries}

The question of who truly belongs to a group is at its root a question about boundaries. Lamont and Molnár (2002) distinguish between social and symbolic boundaries. Social boundaries are "objectified forms of social differences" that limit certain groups from obtaining access to resources and other social opportunities. Symbolic boundaries precede social boundaries, exist at the intersubjective level, and create conceptual distinctions that categorize 
people, practices, or objects. People are creative in their construction of symbolic boundaries, drawing on any multitude of characteristics to designate who is "in" and who is "out."

While separating out those who do not belong, symbolic boundaries bind together those who do (Edgell et al. 2006; Lamont and Molnár 2002). The narrative that the United States is inherently grounded in the Christian faith can create a powerful national boundary marker as it draws upon religious and nationalistic rhetoric to cultivate feelings of similarity and membership (Straughn and Feld 2010) but also powerfully designates out-groups (Braunstein and Taylor 2017). As Chapp (2012:110) points out, those Americans who believe that the United States is Christian will also have a "spiritualized sense of attachment to the United States and understand [their] own citizenship in quasi-religious terms."

The "America as Christian" narrative creates powerful symbolic boundaries because it is not merely highlighting an overlap of religion and politics. Rather, it emphasizes where and how religion and nationality are symbolically aligned and nested within one another, drawing on political and religious criteria (Straughn and Feld 2010). It becomes something all its own, an ideology sui generis. Methodological evidence from various studies supports this point; while controlling for various religion and politics measures believing the United States is inherently Christian is a significant predictor of a variety of attitudes (Froese and Mencken 2009; Perry and Whitehead 2015a, 2015b; Whitehead and Perry 2015).

A growing literature examines the influence of this symbolic boundary on Americans' beliefs, behaviors, and attitudes. Froese and Mencken (2009) find that higher levels of the “America as Christian” identity were predictive of greater support for the Iraq war. McDaniel and colleagues (2011) observe that Americans holding these views report more negative attitudes toward immigrants. People with strong Christian symbolic boundaries also hold less favorable views of interracial family forms (Perry and Whitehead 2015a, 2015b) and are also much more 
likely to view religious diversity (Merino 2010) and same sex marriage (Whitehead and Perry 2015) with antipathy.

Given the broad and varied influence of holding strong symbolic boundaries concerning Christianity and American identity, it is important to examine shifts and patterns in when these boundaries are drawn and who is most likely to use them. Some commentators suggest that the proportion of the population setting such boundaries is increasing almost unchecked (Goldberg 2006). Little empirical evidence is offered in support of such claims, however. Additionally, while prior research shows religious symbolic boundaries are strongly related to various other attitudes, the substantive importance of that association is unknown. It is difficult to identify the relative effect of these beliefs on society at large without knowing if the number of Americans who subscribe to those views is growing or shrinking. Furthermore, the dearth of research focusing on the correlates of religious symbolic boundaries, especially regarding any shifts in those boundaries, leaves a gap in our understanding of the relationship between religion and national identity in the U.S. over time. Finally, since "America is Christian" rhetoric is even versatile enough to draw together religiously diverse groups (Braunstein and Taylor 2017) and can resonate with those even outside conservative Christianity, examinations of temporal variation of this versatile symbolic resource is necessary.

\section{The Expansion and Contraction of the Christian Symbolic Boundary, 1996 - 2014}

Several studies have utilized a question appearing in the 1996 and 2004 General Social Survey that asked respondents how important being Christian is to be truly American to show a rise in Americans' use of the Christian symbolic boundary between those years (Straughn and Feld 2010; see also McDaniel, Nooruddin, and Shortle 2016). Straughn and Feld (2010) theorize that this rise was most likely due to period effects - or "unsettled times" (e.g. 9/11 attacks) where selective intensification among Christians took place and the symbolic boundaries of 
national identity and religion aligned. However, if a rise in 2004 was truly due to cyclical period effects we would need to observe a subsequent decline in this boundary marker in later years. It could be that the 2004 level of the Christian symbolic boundary represented not a rise but a return to "normal" after a drop in 1996. Conversely, it could be that 2004 was an outlier and "normal" is closer 1996 levels. Finally, it may be that 2004 was the first data point of a new "normal" level of the Christian symbolic boundary in the population. Without a later observation, it is impossible to form a definitive conclusion about these possibilities. While adding one additional data point in 2014 cannot adjudicate between all of these possibilities, it is an important step in determining whether or not there was a decline since 2004 or if the selective intensification and symbolic alignment persisted.

There are reasons to suspect, however, that the use of the Christian symbolic boundary declined since that 2004 observation. First, appeals to America's Christian heritage afforded strong preliminary support for the incursions in Iraq and Afghanistan (Froese and Mencken 2009; Smidt 2005). The Bush Administration constantly highlighted Christian ideology when communicating its wartime policy, referred to as the Bush Doctrine. However, dissatisfaction with those wars increased over the years. For instance, Gallup asked the following question in a number of polls from 2001 to 2014: "Thinking now about U.S. military action in Afghanistan that began in October 2001, do you think the United States made a mistake in sending military forces to Afghanistan, or not?" In 2001 and 2002, only 9 and 6 percent of respondents said that it was a mistake. This number grew to 25 percent in 2004, increased to 37 percent in 2009, topping out at 49 percent in 2014 (Gallup 2016b). Furthermore, 2004 was an election year and George W. Bush's approval rating was still relatively high. It declined, however, throughout the rest of his presidency (Gallup 2016a). Steadily increasing discontent with those wars and President 
Bush likely corresponded to a contraction in the proportion of Americans who continued to use "Christian" as a boundary marker of American identity.

Second, starting in 2008 the Obama Administration used a distinctly different brand of religious imagery and ideology than Bush. While the Obama White House was no stranger to the “God Strategy" (Domke and Coe 2010), it employed a much more inclusive religious symbolic boundary marker in what it means to be an American. As Domke and Coe (2010:161) quote in President Obama's first inaugural address, "We are a nation of Christians and Muslims, Jews and Hindus and nonbelievers." This new account was much closer to the pluralist nationalist narrative where citizens' sense of national identity need not hinge on being Christian. The social context began to encourage a more "optimistic pluralism" (Edgell and Tranby 2010) and a greater unwillingness to use religion as a symbolic boundary marker. Due to these shifts in social context - cyclical period effects - we hypothesize that the proportion of Americans who use the Christian symbolic boundary in more recent years will be lower than in 2004 and more comparable to 1996. Specifically, the General Social Survey asked the importance of being Christian question again in 2014, allowing us to add this data point to the known 1996 to 2004 increase in respondents answering positively to this question.

\section{The Multifaceted Symbolic Boundaries of American Identity, 1996 - 2014}

Although past studies have highlighted an increase in the use of the Christian boundary between 1996 and 2004 (Straughn and Feld 2010), it is possible that this was not the only boundary marker that was employed in the wake of the 9/11 attacks. Groups constructing symbolic boundaries are apt to draw on a range of common symbols and shared vocabularies to differentiate insiders and outsiders (Lamont and Molnár 2002; Theiss-Morse 2009). American identity and symbolic boundaries can rotate along various dimensions (Edgell and Tranby 2010). In fact, several studies demonstrate that this particular period of history was not marked by the 
construction of a solely religious symbolic boundary. Rather, people were apt to draw on a host of symbolic resources in order to cultivate feelings of similarity and group membership (McDaniel et al. 2016; Schildkraut 2014; Wong 2010). These findings are in line with research that demonstrates that American identity is multifaceted (Bonikowsi and DiMaggio 2016).

One recent study highlights how various possible symbolic boundary markers of national identity can be drawn upon when groups experience real or existential threat (McDaniel et al. 2016). McDaniel and colleagues (2016) use Terror Management Theory (TMT) in order to examine shifts in American identity from 1996 to 2004. TMT emphasizes the importance of perceived or actual threats to one's mortality and the anxiety that follows such threats. Threats motivate groups to uphold particular cultural values and respond negatively to those who appear to infringe on those values. McDaniel and colleagues (2016), using the same series of questions in the General Social Survey that included the importance of being Christian item, find that from 1996 to 2004 all Americans became more exclusive in their definitions of American identity and did so across a number of different symbolic boundary markers. In times of unrest, Americans will draw on a number of resources to establish symbolic boundaries.

An adjacent line of research also demonstrates that Americans are not exclusive in their use of symbolic boundary markers. This literature finds that American identity contains two overarching classes: civic and ascriptive (Schildkraut 2014). Civic elements are those that describe American identity as a set of beliefs that anyone can hold or actions anyone can do making them much more inclusive. No matter one's race, ethnicity, or place of birth, if they embrace key American ideals then they are American. Examples of civic boundary markers are respecting American laws, or if people "feel American.” Ascriptive elements are much more exclusive and tend to rely on more rigid boundaries of group membership. Examples of ascriptive boundary markers are being Christian, being born in the US, or speaking English. 
Various studies demonstrate that civic elements tend to be more widely endorsed but that ascriptive elements are used by a significant minority of the population (Schildkraut 2007, 2014; Wright, Citrin, and Wand 2012). Religion is only one of a host of possible resources that can be used to construct the symbolic boundaries of American identity.

These two literatures suggest that other civic and ascriptive boundary markers were most likely employed alongside religion. If so, these boundary markers should all exhibit temporal variation from the mid-1990s to the mid-2010s. In order to build upon and extend these studies, we investigate trends for a variety of civic and ascriptive identity dimensions that Americans use as symbolic boundary markers. This allows us to determine if the observed increase and our hypothesized subsequent decrease in Americans using Christianity as a symbolic boundary was unique or whether it was part of broader trends in symbolic boundaries across all dimensions (e.g., race, language, national origins). We hypothesize that the overall trend in Americans' use of Christianity as a symbolic boundary marker was actually part of a larger wave of exclusionary attitudes that rose from 1996 to 2004 and subsequently declined from 2004 to 2014.

\section{The Symbolic Alignment of Christianity and National Identity in 2004}

While boundaries might have been strengthened across many dimensions in the post-9/11 time period, research does suggest that there might have been something distinctive taking place vis-à-vis religious-boundaries and national identity. The events of 9/11 served to alter the religious and national discourse in the United States. This period was marked by sudden swells in national pride alongside decreasing trust of Muslims, immigrants, and other non-Christian religions (Straughn and Feld 2010). ${ }^{1}$ As a result of the September $11^{\text {th }}$ attacks, national identity now had stronger religious assumptions behind it (Williams 2010, 2013). American leaders

\footnotetext{
${ }^{1}$ One example of even non-Muslim religions facing increased discrimination post-9/11: the first 9/11 "revenge killing" was of a Sikh man who was misidentified as Muslim by his attacker.
} 
increasingly used religious rhetoric as a framework for the nation's response to the attacks of September $11^{\text {th }}$ (Bostdorff 2003; Froese and Mencken 2010; Simons 2007). Some even argued that one potential outcome of the increasing salience of American identity in the wake of the 9/11 attacks would be that Americans would make a "recommitment to America as a deeply religious and primarily Christian country" (Huntington 2004). Much of the narrative over the years immediately following those attacks highlighted the religious affiliation of the attackers as well as the terrorist group of which they were a part. In this way, both the national identity of Americans as well as their religious heritage was activated, and the sense of being attacked for those identities would have encouraged greater feelings of "us" versus "them" (Greenberg and Arndt 2011). More Americans, it appears, were drawn to a "cultural preservationist" vision of America (Edgell and Tranby 2010).

This suggests that in the wake of 9/11, Americans with strong national identity (i.e., those who report feeling close to the United States), might have been more likely to point to Christianity as a key marker of what it means to be American. To recall Chapp (2012:110), Americans' sense of attachment to the United States can at times become spiritualized where they begin to recognize their citizenship in quasi-religious terms. National identity and religion became symbolically aligned (Straughn and Feld 2010). Therefore, due to the dramatic period effects in post-9/11 America that raised the salience of religion as it relates to national identity, we hypothesize that there was a significant interaction between national identity and the Christian symbolic boundary in 2004 that did not exist in 1996 or 2014 . We further expect that the extraordinary coupling of national identity and the Christian symbolic boundary marker in 2004 does not exist for the other ascriptive or civic symbolic boundary markers.

\section{Data}


Our data come from three waves (1996, 2004, and 2014) of the General Social Survey

(GSS) (Smith et al. 1972-2014) available from the Association of Religion Data Archives

(theARDA.com). The GSS has been conducted by the National Opinion Research Center

(NORC) since 1972, and biennially since 1994. It uses a personal-interview survey design and a full-probability sampling method which, along with its consistent collection, makes it ideal to examine changes in social attitudes and characteristics. The timing of these three waves in conjunction with the hijackings and attacks of September 11, 2001 creates a sort of natural experiment allowing us to test our predictions concerning the rise and subsequent decline of the Christian symbolic boundary marker in the United States. The data in all subsequent analyses was weighted using WTSSNR.

\section{Outcomes}

The 1996, 2004, and 2014 editions of the GSS included a series of questions with the following prompt: "Some people say the following things are important for being truly American. Others say that they are not important. How important do you think each of the following is...?"2 After this prompt respondents were asked to rate several items as being very important, fairly important, not very important, or not important at all. We classify each of the items as either civic or ascriptive measures of American identity (see Schildkraut 2007). The ascriptive measures include: "To be a Christian," "To have been born in America," “To be able to speak English," and "To have lived in America for most of one's life." The civic measures include: "To respect America's political institutions and laws," "To feel American," and "To

\footnotetext{
${ }^{2}$ One weakness of the wording used in the GSS is that it is impossible to determine if a.) Respondents believe these characteristics are important or b.) If they recognize that these characteristics play a role in determining who is an American, even if they do not agree that they should (Schildkraut 2007). Despite this limitation, a number of studies consider these items valid measures of American identity and each are widely used across the social sciences when examining this concept (e.g. Bonikowski and DiMaggio 2016; Schildkraut 2007, 2014; Theiss-Morse 2009).
} 
have American citizenship." These measures are commonly used in prior analyses to measure American identity (Lamont and Molnár 2002; Schildkraut 2007; Theiss-Morse 2009).

\section{Predictors and Controls}

Our key independent variable concerns feelings of national identification, which is defined as feeling close to America (Theiss-Morse 2009). The GSS asks: "To begin, we have some questions about where you live: your neighborhood or village, your town or city, your county, and so on. How close do you feel to America?" Possible responses included "Very close," "Close," "Not very close," and "Not close at all." We recoded this item so that higher responses indicate greater feelings of closeness.

We expect that religious tradition and religiosity would play a strong role in predicting the "To be a Christian" symbolic boundary in particular. We measure religious affiliation using a typology of religious traditions (Steensland et al. 2000). This separates respondents into one of seven possible traditions: Evangelical Protestant, Mainline Protestant, Black Protestant, Catholic, Jewish, Other religion, or Unaffiliated. Additionally, we account for religious service attendance using a 9-point scale ranging from "Never" to "More than once a week." We also control for other factors that could shape not only the Christian outcome but also the other civic and ascriptive boundary markers. Political affiliation is treated as a categorical measure with respondents coded as either Republican (contrast category), Independent, or Democrat. ${ }^{3}$

We include controls for the respondent's highest level of educational attainment, sex, age, and race. Education is measured as a series of binary variables. Those who completed a BA degree are the contrast category, compared to respondents with less than HS, HS graduate,

\footnotetext{
${ }^{3}$ Biblical literalism and political ideology are two other variables commonly included as controls. We are unable to include either in the following analyses because the 2004 GSS did not include the Bible or political ideology questions on the same ballot as the American identity questions we use as dependent variables.
} 
Associate/Jr College, or Graduate degree. Males serve as the reference category in our analyses. Age is measured continuously, although the value of 89 represents those who are 89 and above. Respondents' race is measured with indicators representing white, black, or those of another race. These are included as dichotomous measures in our analyses with white serving as the reference category.

After excluding cases with missing data on any of our measures (661 cases total), our final analytical sample consists of 3,196 respondents. As a check, we also conducted analyses using multiple imputation of missing data. The results from those models do not differ substantively or statistically from the models presented below. The multiple imputation models and tables are available upon request. Descriptive statistics for all measures can be found in Table 1.

\section{<INSERT TABLE 1 ABOUT HERE $>$}

\section{Results}

Table 2 contains descriptive results across each of the survey years for all of the ascriptive and civic boundary markers. It provides preliminary evidence of the expansion and contraction of the Christian symbolic boundary as well as the multifaceted nature of American symbolic boundaries from 1996 to 2014. We see that in 1996 the percentage of Americans using the Christian symbolic boundary was 38\% and it increased to almost 50\% in 2004. The 2014 edition of the GSS reveals that the percentage fell back to $34 \%$. Interestingly, the Christian-based boundary dropped significantly below its 1996 level in 2014. It appears that the expansion and contraction of the Christian symbolic boundary is not unique, however, as all of the other civic and ascriptive boundary markers increased from 1996 to 2004 and then decreased from 2004 to 2014. These descriptive results suggest that from 1996 to 2014 Americans use of the Christian symbolic boundary expanded and then contracted alongside various other civic and ascriptive 
boundary markers. We move on to multivariate models to ensure these preliminary findings are robust.

\section{<INSERT TABLE 2 ABOUT HERE>}

Given the dependent variables are ordinal we employ ordered logistic regressions in analyzing our outcomes. ${ }^{4}$ Table 3 displays odds ratios, where numbers above one represent an increase in the odds of rating the outcome as more important for being truly American while numbers below one represent a decrease in the odds of rating the outcome as important. These models confirm much of what was seen in the descriptive results presented in Table 2. In 2004 the odds of using each of the civic and ascriptive boundary markers was significantly higher than in 1996. In 2014, however, the odds of respondents using the Christian symbolic boundary and the Feeling American boundary actually fall significantly below the 1996 level. For each of the other boundary markers the odds returned to the 1996 level in 2014. For all seven outcomes the respondent's feeling of closeness to America increases the odds of seeing the characteristic as important for being truly American.

\section{<INSERT TABLE 3 ABOUT HERE>}

Table 4 shows our analyses examining whether there was a symbolic alignment of Christianity and national identity in 2004. In these models we include interaction terms between the year and national identity - or feelings of closeness to America. Because of the inclusion of

\footnotetext{
${ }^{4}$ The ordered but limited number of responses to these questions leads to several potential model choices, including OLS, ordered logistic, or multinomial logistic regression models. Ordered logistic regression appeared to be the best choice, as it utilizes the ordered nature of the responses while also not treating the measure as more continuous than it is. Diagnostics showed that the proportional odds assumption of ordered logistic models was not met, but our overall findings and conclusions did not differ when we examined multinomial logistic regression analyses. Since the results of the multinomial analyses are much more difficult to interpret and present efficiently, we show the ordered logit results here. Results from the multinomial analysis are available upon request. Another potential option was to collapse response categories so that a binary logistic regression analysis could be conducted (Straughn and Feld (2010) use this approach). This seemed less ideal given that it would reduce variation on the dependent variables.
} 
these interaction terms the odds ratio for the feeling of closeness to America represents the association in 1996. The odds ratios for the years represent the differences across years for individuals who do not feel close to America. Looking at the six other symbolic boundary markers, we find that national identity had a significant positive association with the odds of rating these characteristics as important in 1996. Looking at the interaction terms we find no significant difference in this association in 2004 or 2014 with the exception of the "Having citizenship" boundary in 2014. This means that national identity had no special or uniquely powerful association on these outcomes in 2004. To put this in statistical terms, the increases in feelings of closeness to America in 2004 may have raised the intercepts of these outcomes in 2004, but the "closeness slopes" did not change.

\section{<INSERT TABLE 4 ABOUT HERE>}

We find a different pattern for the Christian symbolic boundary marker. Here we find that feeling close to America had no significant effect in 1996 or 2014. In 2004, however, national identity had a significant positive association with the odds of respondents using the Christian symbolic boundary marker. These effects become clearer when we graph predicted probabilities based on these results. Figure 1 shows the predicted probability of using the Christian symbolic boundary - saying "being Christian" is very important to being a "true American" - by year and level of national identity. In 2004 we see that the gap between someone who feels very close and someone who feels not at all close to America is almost twenty-five percentage points. In 1996 and 2014 this gap is less than five percent. To summarize, national identity had a particularly strong and unique association with the Christian symbolic boundary in 2004. In 1996 and 2014, national identity did not appear to have a significant association with the Christian symbolic boundary.

\section{<INSERT FIGURE 1 ABOUT HERE>}




\section{Discussion and Conclusion}

Using the 1996, 2004, and 2014 waves of the GSS we examined the place of religion in the construction of symbolic boundaries. We found that the use of religion, and especially Christianity, as a symbolic boundary marker can exhibit temporal variation and national identity can at times be distinctively aligned with the Christian symbolic boundary. These discoveries advance the study of symbolic boundaries by demonstrating their dynamic nature as well as how their production is contingent on a number of factors suggesting their institutionalization is not inevitable.

We also find that the rise and fall of the Christian symbolic boundary marker was not unique, but was rather a part of a larger wave of exclusionary attitudes. In response to historical events Americans in this period were content to use whatever means necessary, perhaps due to both real and perceived threats, to establish symbolic boundaries and highlight which groups were "in", and which groups were "out". Furthermore, in the decade following 2004 to 2014, Americans were also content to relax the definition of who is considered truly American across all possible boundary markers. This again highlights that there is nothing particularly religious about Americans' creation, maintenance, and subsequent relaxing of national identity markers, but that they are apt to use whatever means necessary to establish symbolic boundaries. Americans are content to utilize a patchwork quilt of symbolic exclusion. Symbolic boundaries and American identity can rotate along multiple dimensions creating a diversity of responses to pluralism and multiculturalism (Edgell and Tranby 2010). Future research on symbolic boundaries and group identity should continue to expand its focus to capture a greater proportion of possible boundary markers. We also encourage future research to theorize why the other civic and ascriptive boundary markers waxed and then waned during this time period. While we posit 
reasons for the expansion and contraction of the Christian symbolic boundary, it is beyond the purview of this study to examine all the other boundary markers in kind.

It will be important to examine the symbolic boundaries formed in other cultures to establish whether its citizens are apt to utilize a patchwork quilt of symbolic exclusion during times of heightened insecurity (Bail 2008; McDaniel et al. 2016). However, such research would benefit from examining symbolic boundaries across time in addition to geographic space and nation-state. Demonstrating the dynamic nature of symbolic exclusion and national identity fills a gap in prior research. The production of symbolic boundaries, the characteristics used to create such boundaries, and the institutionalization of those boundaries are not automatic or forgone conclusions. Attending to not only the creation but dismantling of symbolic boundaries is an important task.

However, while the increased use of the Christian symbolic boundary in 2004 was not unique, there was a uniquely strong association between it and national identity that year. None of the other symbolic boundary markers exhibit such a relationship. In each of the three years for which we have data, increases in an individual's national identity was associated with an increased desire to define American identity using both ascriptive and civic boundary markers. The effect of national identity was the same in 1996, 2004, and 2014 for the non-religion boundary markers. However, the effect of national identity was uniquely associated with excluding individuals on the basis of religion in 2004 while in 1996 and again in 2014 it had no unique role in wanting to exclude individuals for not being Christian.

This strongly suggests that historical events and cultural changes can influence the salience of religion in forming symbolic national boundaries. The events of $9 / 11$ and how they altered the religious and national discourse in the US created a unique symbolic alignment of religion and national identity (Straughn and Feld 2010). Shared identification in particular 
groups became even more pertinent in these "unsettled" times. Americans reacted to the attacks with both increases in national pride as well as decreased trust of non-Christian religious groups, especially Muslims. Assumptions about American identity became suffused with ethnic, racial, and religious meaning (Williams 2010, 2013). The rhetoric of American leaders at the time, particularly George W. Bush, placed the nation's reaction to the September $11^{\text {th }}$ terrorist attacks in a religious framework (Bostdorff 2003; Simons 2007). Drawing explicit attention to the attackers' religion brought into sharp relief the distinctly different nominal religious affiliation of many Americans as well as the dominant religious narrative concerning what it means to be an American. Americans' sense of attachment to the United States, their national identity, became "spiritualized" and they understood their "own citizenship in quasi-religious terms" (Chapp 2012:110). Unlike in 1996, in 2004 individuals who felt close to the US were more likely to point to Christianity as a key marker of American identity. This account follows what Collins (2012) calls "time-bubbles of nationalism" where national crises have an influence on nationalist attitudes, but one that subsequently wanes over time. The current analysis explicitly establishes that such "time-bubbles" exist for religious nationalism as well, in addition to broader forms of nationalism examined in other recent studies (Bonikowski and DiMaggio 2016).

However, the association between feelings of national identity and Christianity faded by 2014. Why? One explanation is that the deprivatization of religion and its reinsertion into the public sphere tends to be cyclical and mostly due to periodic events that raise the salience of religion (Regnerus and Smith 1998). By 2014, much of the cultural, social, and political dynamics present in 2004 had changed dramatically. In 2004 George W. Bush's approval rating was still relatively high, but it would decline throughout the rest of his presidency (Gallup 2016a). 2004 was also an election year, where Bush's leadership during the 9/11 attacks was repeatedly highlighted. Attitudes about the wars in Afghanistan and Iraq also became more 
negative in the decade between the 2004 and 2014 surveys (Gallup 2016b, 2016c). There was not a presidential election in 2014, either. The dramatically different religious rhetoric of the Obama administration, compared to George W. Bush's, also had many more years to permeate the culture. All of these factors appear to have undercut the desire to link Christianity to American identity.

This support for the episodic nature of national religious symbolic boundaries fits with evidence posited by historians that similar trends existed in other historical eras. For instance, Fea (2011) outlines how Christian symbolic boundaries waxed during the presidencies of both Lincoln and Eisenhower during the Civil and Cold Wars, respectively. Both times were marked by varying amounts of civil unrest and collective anxiety about the identity of the United States and its future. During these periods the American public and legislators attempted, with varying degrees of success, to formally recognize the United States as a Christian nation. During the Cold War "In God We Trust" was emblazoned on US currency and "Under God" was added to the pledge of allegiance. Both were attempts to demarcate the United States as a Christian nation in comparison to the "godless" secularists of the Soviet Union and in response to the perceived “creeping socialism” of FDR's New Deal (Herzog 2011; Kruse 2015). Such periods were followed by a time of relative quiet concerning the place of religion in the public sphere. It appears that the decade following 2004 was similar in this respect.

What remains to be seen, however, is how the social and political upheaval from 2014 until the present has influenced Americans' use of various symbolic boundaries. The election of President Trump and the ongoing struggle between his administration and other groups over immigration, religious liberty, and the refugee crisis could be reactivating portions of the American population to concern themselves with what it means to be an American and how this group is delineated from outsiders. Future waves of the GSS may very well evince an increase in 
symbolic boundary markers similar to the increase that took place between 1996 and 2004. The fact that around 80 percent of white, self-identified Evangelical Protestants who were eligible to vote chose Donald Trump (Edgell 2017; Pew 2016), whose campaign hinged on demarcating "real" Americans from outsiders, could signal another period of selective intensification.

It is important to also recognize that the construction of symbolic boundaries designating true American identity will have very real consequences. Symbolic boundaries are regularly translated into social boundaries and social boundaries influence which groups have access to resources and certain civil rights and to which groups these are denied (Edgell et al. 2006; Lamont and Molnár 2002; Straughn and Feld 2010; Theiss-Morse 2009). The Trump administration's repeated attempts at instituting various travel bans, largely regarded as singling out Muslims, are one example of the symbolic being translated to reality. Actions like these and subsequent moves toward creating more strict social boundaries could have unintended consequences. Those with strong national identities set more exclusive symbolic boundaries around who is considered truly American and are much more likely to withhold help from marginalized in-group members and reject any critiques those marginalized in-group members might levy against the group as a whole (Theiss-Morse 2009). These actions serve to weaken the group as they miss out on opportunities to improve the group through recognizing and possibly fixing past mistakes.

Prior research also demonstrates that religious symbolic boundaries are associated with less support for religious diversity creating a more volatile context for religious minorities (Merino 2010). Examples of this abound for Muslim Americans in the wake of $9 / 11$ and more recently due to the Syrian refugee crisis and the first months of the Trump presidency (Bridge Initiative 2016; Morello 2011). Furthermore, the propensity of Americans to highlight certain boundary markers during "unsettled" times could make them much more likely to acquiesce to 
particular political justifications for action. Christian symbolism used by the Bush administration resonated with a particular portion of the public which translated to greater levels of support for the wars in Iraq and Afghanistan (Froese and Mencken 2009). These wars turned out to be costly both in terms of American lives and resources (Londoño 2013). It could be that attempts by the Trump administration to capitalize on Christian symbolic boundaries result in similarly dire outcomes. Future research should continue to investigate the formation, maintenance, and temporal variation of Americans' symbolic boundaries due to these varied consequences. Such boundaries are vital in the distribution of resources and the attainment of status throughout society (Lamont and Molnár 2002).

As with all research, there are a number of limitations that deserve mention. First, we use repeated cross-sections of the American population and are unable to specify exactly why particular individuals adopted and then discarded the Christian symbolic boundary. We are limited by the fact that no panel data exists that contains questions like those used in this analysis. Researchers also highlight the various traditions within American identity. Ethnoculturalism and civic republicanism, for the most part, encompass the questions examined in this study but liberalism and incorporationism are also found to influence where, when, and how people draw boundaries of American identity (Schildkraut 2002, 2007, 2014). Continuing to expand the measures used to delineate the symbolic boundaries of American identity is important for future research and upcoming waves of the GSS. 


\section{References}

Bail, Christopher. 2008. "The Configuration of Symbolic Boundaries against Immigrants in Europe.” American Sociological Review 73(1):37-59.

Bonikowski, Bart and Paul DiMaggio. 2016. "Varieties of American Popular Nationalism." American Sociological Review DOI: 10.1177/0003122416663683.

Bostdorff, Denise M. 2003. “George W. Bush's Post-September 11 Rhetoric of Covenant Renewal: Upholding the Faith of the Greatest Generation." Quarterly Journal of Speech 89(4): 293-319.

Braunstein, Ruth and Malaena Taylor. 2017. "Is the Tea Party a 'Religious' Movement? Religiosity in the Tea Party versus the Religious Right.” Sociology of Religion 78(1):3359.

Bridge Initiative. 2016. "When Islamophobia Turns Violent: The 2016 U.S. Presidential Elections." Available at: http://bridge.georgetown.edu/when-islamophobia-turns-violentthe-2016-u-s-presidential-elections/.

Chapp, Christopher B. 2012. Religious Rhetoric and American Politics: The Endurance of Civil Religion in Electoral Campaigns. Ithaca, NY: Cornell University Press.

Collins, Randall. 2012. "Time-Bubbles of Nationalism: Dynamics of Solidarity Ritual in Lived Time." Nations and Nationalism 18(3):383-397.

Domke, David and Kevin Coe. 2010. The God Strategy: How Religion Became a Political Weapon in America. New York, NY: Oxford University Press.

Edgell, Penny. 2017. "An Agenda for Research on American Religion in Light of the 2016 Election." Sociology of Religion 78(1):1-8.

Edgell, Penny, Joseph Gerteis, and Douglas Hartmann. 2006. “Atheists as 'Other': Moral Boundaries and Cultural Membership in American Society.” American Sociological Review 71:211-234.

Edgell, Penny, Douglas Hartmann, Evan Stewart, and Joseph Gerteis. 2016. "Atheists and Other Cultural Outsiders: Moral Boundaries and the Non-Religious in the United States." Social Forces 95(2):607-638.

Edgell, Penny and Eric Tranby. 2010. "Shared Visions? Diversity and Cultural Membership in American Life." Social Problems 57(2):175-204.

Fea, John. 2011. Was America Founded as a Christian Nation? A Historical Introduction. Louisville, KY: Westminster John Knox Press. 
Finke, Roger. 1990. "Religious Deregulation: Origins and Consequences." Journal of Church and State 32(3):609-626.

Froese, Paul and F. Carson Mencken. 2009. "A U.S. Holy War? The Effects of Religion on Iraq War Policy Attitudes.” Social Science Quarterly 90(1):103-116.

Gallup 2016a. "Presidential Approval Ratings-George W. Bush." Accessed at Gallup.com on July 28, 2016.

Gallup 2016b. "War on Terrorism.” Accessed at Gallup.com on July 28, 2016.

Gallup 2016c. "Iraq.” Accessed at Gallup.com on July 28, 2016.

Goldberg, Michelle. Kingdom Coming: The Rise of Christian Nationalism. New York, NY: W.W. Norton \& Company, Inc.

Green, Steven K. 2015. Inventing a Christian America: The Myth of the Religious Founding. New York, NY: Oxford University Press.

Greenberg, Jeff and Jamie Arndt. Year. "Terror Management Theory.” In Handbook of Theories of Social Psychology, Van Lange, Paul A. M., Arie W. Kruglanski, and E. Tory Higgins (Eds.), pp. 398-415.

Herzog, Jonathan P. 2011. The Spiritual-Industrial Complex: America's Religious Battle against Communism in the Early Cold War. New York, NY: Oxford University Press.

Huntington, Samuel P. 2004. Who Are We? America's Great Debate. New York: Simon \& Schuster.

Kruse, Kevin M. 2015. One Nation Under God: How Corporate America Invented Christian America. New York, NY: Basic Books.

Lamont, Michèle and Virág Molnár. 2002. "The Study of Boundaries in the Social Sciences." Annual Review of Sociology 28:167-195.

Londoño, Ernesto. 2013. "Study: Iraq, Afghan War Costs to Top $\$ 4$ Trillion.” The Washington Post. Available at: https://www.washingtonpost.com/world/national-security/study-iraqafghan-war-costs-to-top-4-trillion/2013/03/28/b82a5dce-97ed-11e2-814b063623d80a60_story.html. Last accessed on June 24, 2016

McDaniel, Eric L., Irfan Nooruddin, Allyson Faith Shortle. 2011. "Divine Boundaries: How Religion Shapes Citizens Attitudes toward Immigrants.” American Politics Research 39: 205-233.

McDaniel, Eric L., Irfan Nooruddin, Allyson Faith Shortle. 2016. "Proud to be an American? The Changing Relationship of National Pride and Identity." The Journal of Race, Ethnicity, and Politics 1(1):145-176. 
Merino, Stephen. 2010. "Religious Diversity in a 'Christian Nation': The Effects of Theological Exclusivity and Interreligious Contact on the Acceptance of Religious Diversity." Journal for the Scientific Study of Religion 49:231-46.

Morello, Carol. 2011. "Muslim Americans Say Life is More Difficult Since 9/11." The Washington Post, August 30. Available at: https://www.washingtonpost.com/local/muslim-americans-say-life-is-more-difficultsince-911/2011/08/29/gIQA7W8foJ_story.html.

Perry, Samuel L. and Andrew L. Whitehead. 2015a. "Christian Nationalism and White Racial Boundaries: Examining Whites' Opposition to Interracial Marriage.” Ethnic and Racial Studies DOI: 10.1080/01419870.2015.1015584.

Perry, Samuel L. and Andrew L. Whitehead. 2015b. "Christian Nationalism, Racial Separatism, and Family Formation: Attitudes toward Transracial Adoption as a Test Case." Race and Social Problems DOI: 10.1007/s12552-015-9144-7.

Pew Research Center. 2016. "How the Faithful Voted: A Preliminary 2016 Analysis." Accessed at Pewresearch.org on April 3, 2016.

Regnerus, Mark D. and Christian Smith. 1998. "Selective Deprivation among American Religious Traditions: The Reversal of the Great Reversal.” Social Forces 76(4):1347-72.

Schildkraut, Deborah J. 2002. "The More Things Change...American Identity and Mass and Elite Responses to 9/11.” Political Psychology 23(3):511-535.

Schildkraut, Deborah J. 2007. "Defining American Identity in the Twenty-First Century: How Much 'There' is There?" The Journal of Politics 69(3):597-615.

Schildkraut, Deborah J. 2011. "National Identity in the United States." In The Handbook of Identity Theory and Research, Schwartz, Seth J., Koen Luyckx, and Vivian Vignoles (Eds.), pp. 845-865.

Schildkraut, Deborah J. 2014. "Boundaries of American Identity: Evolving Understandings of 'Us'." Annual Review of Political Science 17:441-460.

Simons, Herbert W. 2007. "From Post-9/11 Melodrama to Quagmire in Iraq: A Rhetorical History.” Rhetoric \& Public Affairs 10(2): 183-194.

Smidt, Corwin E. 2005. "Religion and American Attitudes Toward Islam and an Invasion of Iraq." Sociology of Religion 66(3):243-261.

Smith, Tom W, Peter Marsden, Michael Hout, and Jibum Kim. General Social Surveys, 19722014. 
Steensland, B., J. Z. Park, M. D. Regnerus, L. D. Robinson, W. B. Wilcox, and R. D. Woodberry. 2000. The measure of American religion: Toward improving the state of the art. Social Forces, 79(1): 291-318.

Straughn, Jeremy Brooke and Scott L. Feld. 2010. “America as a 'Christian Nation'? Understanding Religious Boundaries of National Identity in the United States." Sociology of Religion 71(3):280-306.

Theiss-Morse, Elizabeth. 2009. Who Counts as an American? The Boundaries of National Identity. New York, NY: Cambridge University Press.

Whitehead, Andrew L. and Samuel L. Perry. 2015. "A More Perfect Union? Christian Nationalism and Support for Same-Sex Unions.” Sociological Perspectives 58(3):422440.

Williams, Rhys. H. 2010. "Muslim in America.” The Christian Century 127(12):32-36.

Williams, Rhys. H. 2013. "Civil Religion and the Cultural Politics of National Identity in Obama's America.” Journal for the Scientific Study of Religion 52(2):239-257.

Wong, Cara. 2010. Boundaries of Obligation in American Politics: Geographic, National, and Racial Communities. New York, NY: Cambridge University Press.

Wright, Matthew, Jack Citrin, Jonathan Wand. 2012. Alternative measures of American national identity: Implications for the civic-ethnic distinction. Political Psychology 33:469-482. 
Table 1: Descriptive Means or Percentages Overall and By Year

\begin{tabular}{|c|c|c|c|c|c|}
\hline & Range & $\begin{array}{c}\text { Overall Mean } \\
\text { or } \%\end{array}$ & 1996 & 2004 & 2014 \\
\hline \multicolumn{6}{|l|}{ Importance of... } \\
\hline \multicolumn{6}{|l|}{ Ascriptive boundaries } \\
\hline Being Christian & $1-4$ & 2.7 & 2.7 & 3.0 & 2.5 \\
\hline Being Born in America & $1-4$ & 3.1 & 3.0 & 3.3 & 3.0 \\
\hline Speaking English & $1-4$ & 3.7 & 3.6 & 3.8 & 3.6 \\
\hline In America for Life & $1-4$ & 3.2 & 3.1 & 3.4 & 3.1 \\
\hline \multicolumn{6}{|l|}{ Civic boundaries } \\
\hline Respect Laws & $1-4$ & 3.6 & 3.6 & 3.7 & 3.3 \\
\hline Feel American & $1-4$ & 3.5 & 3.5 & 3.6 & 3.4 \\
\hline Have Citizenship & $1-4$ & 3.7 & 3.6 & 3.8 & 3.6 \\
\hline Closeness to America & $1-4$ & 3.3 & 3.1 & 3.4 & 3.3 \\
\hline \multicolumn{6}{|l|}{ Year } \\
\hline 1996 & -- & $34.9 \%$ & -- & -- & -- \\
\hline 2004 & -- & $32.5 \%$ & -- & -- & -- \\
\hline 2014 & -- & $32.6 \%$ & -- & -- & -- \\
\hline \multicolumn{6}{|l|}{ Religious Tradition } \\
\hline Evangelical Prot. & -- & $26.3 \%$ & $26.7 \%$ & $26.6 \%$ & $25.6 \%$ \\
\hline Mainline Prot. & -- & $15.9 \%$ & $19.8 \%$ & $14.5 \%$ & $13.1 \%$ \\
\hline Black Prot. & -- & $6.9 \%$ & $8.1 \%$ & $6.6 \%$ & $5.9 \%$ \\
\hline Catholic & -- & $27.2 \%$ & $25.3 \%$ & $28.0 \%$ & $28.5 \%$ \\
\hline Jewish & -- & $1.8 \%$ & $1.7 \%$ & $2.6 \%$ & $1.1 \%$ \\
\hline Other Religion & -- & $6.7 \%$ & $7.3 \%$ & $7.8 \%$ & $5.0 \%$ \\
\hline Unaffiliated & -- & $15.2 \%$ & $11.2 \%$ & $14.0 \%$ & $21.0 \%$ \\
\hline Religious Service Attendance & $0-8$ & 3.7 & 3.8 & 3.9 & 3.5 \\
\hline \multicolumn{6}{|l|}{ Political Party ID } \\
\hline Democrat & -- & $34.4 \%$ & $35.3 \%$ & $35.1 \%$ & $32.6 \%$ \\
\hline Independent & -- & $37.9 \%$ & $35.7 \%$ & $33.8 \%$ & $44.3 \%$ \\
\hline Republican & -- & $27.8 \%$ & $29.0 \%$ & $31.1 \%$ & $23.2 \%$ \\
\hline \multicolumn{6}{|l|}{ Education } \\
\hline Less than HS Degree & -- & $11.2 \%$ & $13.4 \%$ & $8.9 \%$ & $11.3 \%$ \\
\hline HS Degree & -- & $52.2 \%$ & $55.5 \%$ & $51.1 \%$ & $49.8 \%$ \\
\hline Assoc./Junior College & -- & $8.3 \%$ & $6.5 \%$ & $9.1 \%$ & $9.3 \%$ \\
\hline Bachelor's Degree & -- & $19.0 \%$ & $16.7 \%$ & $21.2 \%$ & $19.2 \%$ \\
\hline Graduate Degree & -- & $9.4 \%$ & $7.9 \%$ & $9.8 \%$ & $10.5 \%$ \\
\hline Female & -- & $54.7 \%$ & $55.1 \%$ & $55.5 \%$ & $53.4 \%$ \\
\hline Age & $18-89$ & 45.5 & 44.2 & 44.6 & 47.7 \\
\hline \multicolumn{6}{|l|}{ Race } \\
\hline White & -- & $79.0 \%$ & $82.1 \%$ & $79.7 \%$ & $75.0 \%$ \\
\hline Black & -- & $12.5 \%$ & $12.3 \%$ & $12.2 \%$ & $13.1 \%$ \\
\hline Other & -- & $8.5 \%$ & $5.6 \%$ & $8.0 \%$ & $11.9 \%$ \\
\hline $\mathrm{N}$ & & 3,196 & 1,118 & 1,042 & 1,036 \\
\hline
\end{tabular}

Data: GSS (1996, 2004, 2014); Analyses weighted with WTSSNR 
Table 2: Trends in Exclusionary Attitudes and Feelings of Closeness to America

\begin{tabular}{|c|c|c|c|}
\hline & 1996 & 2004 & 2014 \\
\hline \multicolumn{4}{|c|}{ Percent Saying "Very Important" to [...] to be Truly American } \\
\hline \multicolumn{4}{|c|}{ Ascriptive boundaries } \\
\hline Being Christian & $38.2 \%$ bc & $49.6 \%{ }^{\mathrm{ac}}$ & $33.7 \%{ }^{\mathrm{ab}}$ \\
\hline Being Born in America & $40.3 \%{ }^{\mathrm{b}}$ & $55.5 \%$ ac & $41.7 \%^{\mathrm{b}}$ \\
\hline Speaking English & $71.7 \%^{\mathrm{b}}$ & $83.3 \%$ ac & $72.8 \%^{\mathrm{b}}$ \\
\hline In America for Life & $44.9 \%{ }^{\mathrm{b}}$ & $58.9 \%{ }^{\mathrm{ac}}$ & $42.3 \%^{\mathrm{b}}$ \\
\hline \multicolumn{4}{|l|}{ Civic boundaries } \\
\hline Respect Laws & $64.8 \%{ }^{\mathrm{b}}$ & $74.3 \%$ ac & $66.0 \%^{\mathrm{b}}$ \\
\hline Feel American & $62.0 \%$ b & $69.9 \%{ }^{\mathrm{ac}}$ & $59.2 \%^{\mathrm{b}}$ \\
\hline Have Citizenship & $74.4 \%{ }^{\mathrm{b}}$ & $81.9 \%{ }^{\mathrm{ac}}$ & $71.9 \%{ }^{\mathrm{b}}$ \\
\hline Percent Feeling "Very Close" to America & $35.3 \% \mathrm{~b}$ & $50.9 \%{ }^{\mathrm{a}}$ & $43.2 \%$ \\
\hline
\end{tabular}

Data: GSS (1996, 2004, 2014); Analyses weighted with WTSSNR; N=3,169;
a. Different from 1996 percentage at $p<.05$
b. Different from 2004 percentage at $p<.05$
c. Different from 2012 percentage at $p<.05$ 
Table 3: Ordered logistic regression results (Odds Ratios Shown; Coefficients $>1=$ increased likelihood of saying characteristic is important; Coefficients $<1=$ decreased likelihood of saying characteristic is important)

\begin{tabular}{|c|c|c|c|c|c|c|c|}
\hline & \multicolumn{7}{|c|}{ Importance of $[\ldots]$ for being Truly American } \\
\hline & \multicolumn{4}{|c|}{ Ascriptive boundaries } & \multicolumn{3}{|c|}{ Civic boundaries } \\
\hline & $\begin{array}{c}\text { Being } \\
\text { Christian } \\
\end{array}$ & $\begin{array}{c}\text { Being Born in } \\
\text { America }\end{array}$ & $\begin{array}{l}\text { Speaking } \\
\text { English }\end{array}$ & $\begin{array}{c}\text { In America } \\
\text { for Life }\end{array}$ & Respect Laws & Feel American & $\begin{array}{c}\text { Have } \\
\text { citizenship }\end{array}$ \\
\hline \multicolumn{8}{|l|}{ Year } \\
\hline 1996 (ref.) & -- & -- & -- & -- & -- & -- & -- \\
\hline 2004 & $2.04 * *$ & $1.91 * *$ & $2.01 * *$ & $1.86^{* *}$ & $1.46^{* *}$ & $1.37 * *$ & $1.49 * *$ \\
\hline 2014 & $.75^{* *}$ & 1.07 & 1.01 & .88 & 1.04 & $.81 *$ & .87 \\
\hline Feels Close to US & $1.15^{*}$ & $1.16^{* *}$ & $1.39 * *$ & $1.32 * *$ & $1.59 * *$ & $1.90 * *$ & $1.71 * *$ \\
\hline \multicolumn{8}{|l|}{ Religious Tradition } \\
\hline Evangelical Prot. (ref.) & -- & -- & -- & -- & -- & -- & -- \\
\hline Mainline Prot. & $.49 * *$ & $.69 * *$ & $.63 * *$ & .79 & .90 & $.76^{*}$ & $.61 * *$ \\
\hline Black Prot. & $.51 * *$ & .93 & .62 & 1.00 & $.59 *$ & .77 & .61 \\
\hline Catholic & $.45^{* *}$ & $.79 *$ & .88 & .95 & $.77 *$ & .82 & .80 \\
\hline Jewish & $.03 * *$ & $.36 * *$ & .69 & $.43 * *$ & .67 & .57 & .77 \\
\hline Other Religion & $.17 * *$ & $.46^{* *}$ & $.62 *$ & $.58 * *$ & .75 & $.47 * *$ & $.54 * *$ \\
\hline Unaffiliated & $.16^{* *}$ & $.54 * *$ & $.50 * *$ & $.70 * *$ & $.56 * *$ & $.59 * *$ & $.48 * *$ \\
\hline $\begin{array}{l}\text { Religious Service } \\
\text { Attendance }\end{array}$ & $1.23 * *$ & .99 & .99 & 1.00 & $1.06^{* *}$ & 1.01 & 1.02 \\
\hline \multicolumn{8}{|l|}{ Political Party ID } \\
\hline Democrat & .91 & .95 & $.62 * *$ & .90 & $.77 *$ & $.71 * *$ & $.61 * *$ \\
\hline Independent & .88 & $.76^{* *}$ & $.74 *$ & $.78^{*}$ & $.66 * *$ & $.74 * *$ & $.61 * *$ \\
\hline Republican (ref.) & -- & -- & -- & -- & -- & -- & -- \\
\hline \multicolumn{8}{|l|}{ Education } \\
\hline Less than HS Degree & $5.09 * *$ & $3.86 * *$ & $2.23 * *$ & $4.10 * *$ & 1.02 & $1.67 * *$ & $1.59 *$ \\
\hline HS Degree & $2.46 * *$ & $2.15 * *$ & $1.62 * *$ & $1.98 * *$ & .98 & 1.21 & $1.78 * *$ \\
\hline Assoc./Junior College & $1.57 * *$ & $1.85 * *$ & 1.37 & $1.64 * *$ & 1.02 & 1.09 & $1.64 * *$ \\
\hline Bachelor's Degree (ref.) & -- & -- & -- & -- & -- & -- & -- \\
\hline Graduate Degree & $.64 * *$ & $.73^{*}$ & $.72 *$ & $.73 *$ & .90 & $.70^{*}$ & .79 \\
\hline Female & $1.33 * *$ & 1.13 & $1.35 * *$ & $1.19 *$ & 1.16 & 1.13 & $1.22 *$ \\
\hline Age & $1.02 * *$ & $1.01 * *$ & $1.02 * *$ & $1.01 * *$ & $1.01 * *$ & $1.02 * *$ & $1.01 * *$ \\
\hline \multicolumn{8}{|l|}{ Race } \\
\hline White (ref.) & -- & -- & -- & -- & -- & -- & -- \\
\hline Black & $3.46 * *$ & $1.69 * *$ & $1.88 * *$ & $1.98 * *$ & 1.22 & .86 & $2.04 * *$ \\
\hline Other & 1.03 & .75 & $1.48 *$ & 1.24 & 1.35 & .94 & .97 \\
\hline
\end{tabular}

Data: GSS (1996, 2004, 2014); Analyses weighted with WTSSNR; N=3,196; *p>.05; **p<.01 
Table 4: Ordered logistic regression results with interaction terms between closeness to U.S. and year (Odds Ratios Shown; Coefficients $>1=$ increased likelihood of saying characteristic is important; Coefficients $<1=$ decreased likelihood of saying characteristic is important)

\begin{tabular}{|c|c|c|c|c|c|c|c|}
\hline & \multicolumn{7}{|c|}{ Importance of $[\ldots]$ for being Truly American } \\
\hline & \multicolumn{4}{|c|}{ Ascriptive boundaries } & \multicolumn{3}{|c|}{ Civic boundaries } \\
\hline & $\begin{array}{c}\text { Being } \\
\text { Christian }\end{array}$ & $\begin{array}{l}\text { Being Born } \\
\text { in America }\end{array}$ & $\begin{array}{c}\text { Speaking } \\
\text { English }\end{array}$ & $\begin{array}{l}\text { In America } \\
\text { for Life }\end{array}$ & Respect Laws & Feel American & $\begin{array}{c}\text { Have } \\
\text { citizenship }\end{array}$ \\
\hline \multicolumn{8}{|l|}{ Year } \\
\hline 1996 (ref.) & -- & -- & -- & -- & -- & -- & -- \\
\hline 2004 & .69 & 2.11 & 1.97 & 1.39 & 1.89 & .74 & 1.58 \\
\hline 2014 & .85 & 1.90 & 1.44 & 1.20 & 1.72 & .86 & $2.61 *$ \\
\hline Feels Close to US & 1.05 & $1.23 * *$ & $1.44 * *$ & $1.34 * *$ & $1.72 * *$ & $1.81 * *$ & $1.98 * *$ \\
\hline \multicolumn{8}{|l|}{ Period Specific Closeness Effects } \\
\hline 1996 X Feels Close to US (ref.) & -- & -- & -- & -- & -- & -- & -- \\
\hline 2004 X Feels Close to US & $1.38 *$ & .96 & 1.00 & 1.09 & .91 & 1.21 & .97 \\
\hline 2014 X Feels Close to US & .96 & .83 & .89 & .90 & .85 & .98 & $.69 * *$ \\
\hline
\end{tabular}

Data: GSS (1996, 2004, 2014); Analyses weighted with WTSSNR; N=3,196; *p>.05; **p<.01

Note: Coefficients for the control variables are almost identical to models in Table 3 and so are not included here in the interest of space.

Full results are available upon request. 
Figure 1-Predicted Probability of Saying that it is Very Important to be Christian by Year and National Identity

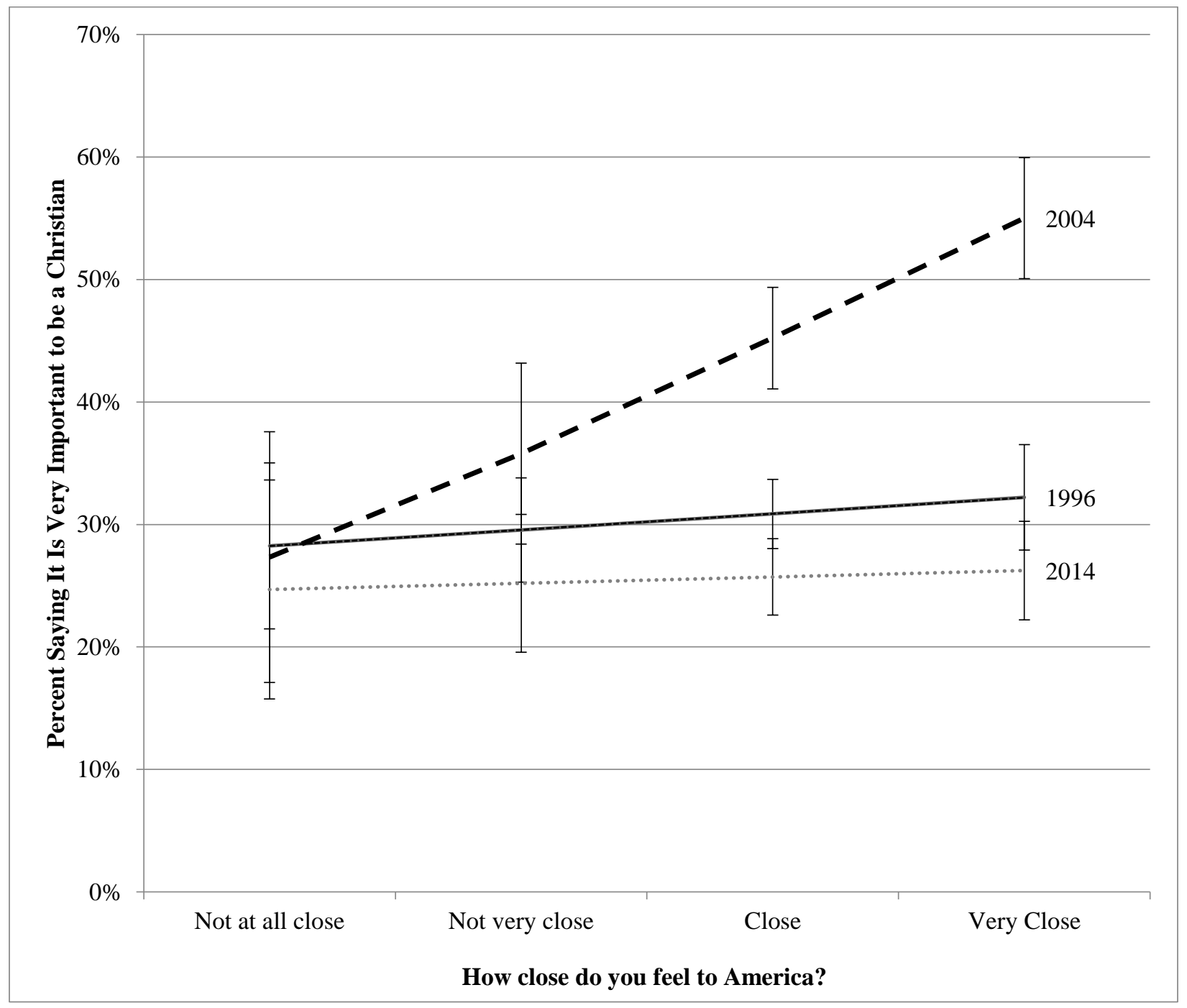

Note: Based on results shown in table 4 with all other predictors set at their means. Bars represent $95 \%$ confidence intervals 